\title{
PENGARUH MOTIVASI WIRAUSAHA TERHADAP MINAT BERWIRAUSAHA MAHASISWA
}

\author{
Westri Andayanti, Subhan Harie \\ Universitas Indraprasta PGRI, Jakarta \\ westri2014@gmail.com, subhanharie@gmail.com
}

\begin{abstract}
ABSTRAK
Penelitian ini bertujuan untuk mengetahui dan menganalisis pengaruh motivasi wirausaha terhadap minat berwirausaha mahasiswa. Metode penelitian survei dengan menggunakan Google Form, pendekatan penelitian kuantitatif dengan format eksplanasi. Terdapat pengaruh parsial yang positif dan signifikan antara motivasi wirausaha terhadap minat berwirausaha mahasiswa; dan terdapat pengaruh simultan yang positif dan signifikan motivasi wirausaha terhadap minat berwirausaha mahasiswa. Kesimpulan penelitian ini adalah variabel motivasi wirausaha bukan satu satunya variabel yang mempengaruhi minat berwirausaha. Untuk itu perlu juga dikembangkan penelitian pada variabel untuk mendapatkan pembaruan.
\end{abstract}

Kata kunci: motivasi wirausaha, minat berwirausaha

\section{ENTREPRENEURIAL MOTIVATION IMPACT TOWARD ENTREPRENEURSHIP INTEREST OF COLLEGE STUDENT}

\begin{abstract}
This study aims to determine and analyze the effect of entrepreneurial motivation on students' interest in entrepreneurship. The survey research method uses Google Form, a quantitative research approach with an explanatory format. There is a positive and significant partial influence between entrepreneurial motivation on students' interest in entrepreneurship; and there is a positive and significant simultaneous influence of entrepreneurial motivation on students' interest in entrepreneurship. The conclusion of this study is that the entrepreneurial motivation variable is not the only variable that affects interest in entrepreneurship. For this reason, it is also necessary to develop research on variables to get updates.
\end{abstract}

Keywords: entrepreneurial motivation, entrepreneurship interest

\section{PENDAHULUAN}

Perguruan tinggi atau universitas merupakan lembaga yang membentuk lulusan menjadi pribadi yang cerdas, kreatif, dan mandiri sehingga memiliki softskill dan hardskill yang berkualitas. Berbagai fakultas, jurusan atau program studi yang ditawarkan seharusnya disesuaikan dengan kebutuhan pasar tenaga kerja yang ada. Perguruan Tinggi harus dapat membentuk pribadi mahasiswa yang berani mengambil risiko dan memiliki jiwa entrepreneurship. Oleh karena itu sebuah pendidikan tinggi harus berupaya menumbuhkan minat mahasiswanya untuk berwirausaha, salah satunya dengan memberikan mata kuliah Kewirausahaan. Tujuan dari mata kuliah Kewirausahaan ini adalah untuk memberikan landasan teoritis mengenai konsep kewirausahaan.

Pada 2009 Pemerintah melalui Direktorat Jenderal Pendidikan Tinggi Kementerian Pendidikan dan Kebudayaan telah meluncurkan Program Mahasiswa Wirausaha (PMW) untuk dilaksanakan dan dikembangkan oleh perguruan tinggi. Program tersebut dilaksanakan di seluruh perguruan tinggi negeri (PTN) dan di beberapa perguruan tinggi swasta (PTS). Program ini bertujuan untuk memberikan bekal pengetahuan, keterampilan dan sikap atau jiwa wirausaha 


\section{Westri Andayanti, Subhan Harie \\ Universitas Indraprasta PGRI}

(entrepreneurship) berbasis IPTEK kepada para mahasiswa agar dapat mengubah pola pikir (mindset) dari pencari kerja (job seeker) menjadi pencipta lapangan pekerjaan (job creator) serta menjadi calon pengusaha yang tangguh dan sukses menghadapi persaingan global. Di samping itu juga untuk mendorong kelembagaan atau unit kewirausahaan di perguruan tinggi agar dapat mendukung pengembangan program-program kewirausahaan. Sebagai hasil akhir, diharapkan terjadinya penurunan angka pengangguran lulusan pendidikan tinggi.

Minat berwirausaha merupakan ketertarikan seseorang untuk menciptakan suatu usaha dengan melihat peluang yang ada di sekitar dan berani mengambil risiko yang kemungkinan terjadi dalam menjalankan usaha (Atmaja, 2016). Mahasiswa yang berminat untuk berwirausaha akan terlihat pada tingkah laku yang menunjukkan keinginannya yang timbul dari dalam diri dengan berani menanggung risiko dan cepat tanggap dalam menangani peluang yang ada. Inti dari minat berwirausaha adalah dorongan dan ketertarikan seseorang untuk melakukan tindakan yang inovatif dan kreatif dalam memanfaatkan sumber daya berupa tenaga kerja, bahan mentah, dan modal untuk menghasilkan sebuah produk baru demi tercapainya kesejahteraan individu dan masyarakat. Beberapa variabel diduga berpengaruh terhadap minat berwirausaha mahasiswa, di antaranya pembelajaran motivasi wirausaha mahasiswa.

Motivasi wirausaha mahasiswa diduga berpengaruh terhadap minat berwirausaha mahasiswa. Motivasi merupakan suatu daya pendorong atau penggerak seseorang untuk berperilaku tertentu yang dapat timbul dari dalam atau luar individu. Motivasi adalah dorongan baik dari orang lain maupun dari diri sendiri untuk mengerjakan suatu pekerjaan dengan sadar dan semangat untuk mencapai target tertentu (Mulyadi, 2015). Dorongan ini berada pada diri seseorang yang menggerakkan untuk melakukan sesuatu yang sesuai dengan dorongan dalam dirinya. Oleh karena itu, perbuatan seseorang yang didasarkan atas motivasi tertentu mengandung tema sesuai dengan motivasi yang mendasari.

Motivasi merupakan suatu unsur perangsang keinginan (want) daya penggerak kemauan bekerja seseorang terhadap tujuan tertentu yang ingin dicapai. Peran motivasi dalam berwirausaha dapat dianalogikan sebagai bahan bakar penggerak mesin. Motivasi usaha yang memadai akan mendorong untuk berperilaku aktif dalam berwirausaha (Sunyoto, 2012). Motivasi merupakan daya penggerak kemauan bekerja seseorang terhadap tujuan yang dicapai. Wirausaha adalah orang yang memiliki kreativitas dan inovatif sehingga mampu menggali dan menemukan peluang dan mewujudkan menjadi usaha yang menghasilkan nilai atau laba (Basrowi, 2016). Wirausaha merupakan seseorang yang memiliki kreatif dan inovatif serta menghadapi risiko yang mampu menciptakan peluang menjadi usaha yang menghasilkan nilai atau laba.

Motivasi dalam konteks kewirausahaan sebagai keseluruhan elemen daya penggerak di dalam diri seorang wirausaha yang menimbulkan kegiatan wirausaha yang menjamin kelangsungan dari kegiatan wirausaha dan yang memberi arah pada kegiatan wirausaha tersebut sehingga tujuan yang dikehendaki dapat tercapai (Wikanso, 2013). Motivasi usaha merupakan suatu kerelaan untuk berusaha seoptimal mungkin dalam mencapai tujuan organisasi yang dipengaruhi oleh kemampuan usaha untuk memuaskan beberapa kebutuhan individu (Gemina Silaningsih, \& Yuningsih, 2016). Dengan demikian, motivasi wirausaha merupakan daya penggerak di dalam diri seorang wirausaha untuk mencapai tujuan.

Seorang Wirausaha akan muncul ketika individu tersebut berani mengembangkan usahausaha dan ide-ide barunya, membuat seseorang menjadi berani mengembangkan usaha dan idenya melalui motivasi berwirausaha yang kuat (Minola, Criaco, \& Obschonka, 2016). Mata kuliah kewirausahaan berpengaruh terhadap minat berwirausaha mahasiswa. Materi yang disampaikan memiliki peran besar bagi mahasiswa, karena dengan diberikannya materi-materi yang baru maka wawasan mahasiswa akan bertambah. Selain itu, cara penyampaian materi yang baik akan menimbulkan pemahaman yang mendalam bagi mahasiswa sehingga mahasiswa dapat 
menguasai pembelajaran yang telah diberikan (Ramadhani \& Nurnida, 2017). Mata kuliah kewirausahaan memberikan pengaruh terhadap minat mahasiswa berwirausaha. Semakin banyak mahasiswa memperoleh pemahaman materi tentang kewirausahaan tentu akan meningkatkan minat mahasiswa dalam berwirausaha (Wiyadi \& Rochmania, 2016).

Berdasarkan beberapa jurnal nasional dan internasional di atas, maka akan dibahas mengenai motivasi wirausaha dan minat berwirausaha, yang diteliti secara terpisah. Kebaruan atau novelty pada penelitian ini mengenai minat berwirausaha mahasiswa yang dipengaruhi motivasi wirausaha belum pernah dilakukan sebelumnya. Perumusan masalah penelitian adalah, apakah terdapat pengaruh parsial motivasi wirausaha terhadap minat berwirausaha mahasiswa? Selain itu, apakah terdapat pengaruh simultan motivasi wirausaha terhadap minat berwirausaha mahasiswa?

\section{METODOLOGI PENELITIAN}

Metode penelitian yang digunakan pada penelitian ini adalah survei. Metode survei merupakan suatu penyelidikan yang sistematis dengan mengumpulkan informasi yang berhubungan dengan obyek studi (Yusuf, 2016). Pendekatan yang digunakan adalah pendekatan kuantitatif dengan format eksplanasi. Pendekatan kuantitatif merupakan penelitian yang menggunakan analisis data yang berbentuk numerik atau data (Suryani \& Hendriyadi, 2016). Format eksplanasi merupakan penjelasan suatu generalisasi sampel terhadap populasinya, atau pengaruh satu variabel dengan variabel yang lain (Bungin, 2017).

Obyek penelitian terdiri dari motivasi wirausaha sebagai variabel bebas, sedangkan minat berwirausaha mahasiswa sebagai variabel terikat. Lokasi penelitian di Universitas Indraprasta PGRI Jakarta, yang dilaksanakan pada Maret sampai Juni 2020. Populasi penelitian adalah seluruh mahasiswa Universitas Indraprasta PGRI Jakarta, sedangkan sampelnya berjumlah 94 mahasiswa di Universitas Indraprasta PGRI Jakarta. Uji coba instrumen penelitian sebanyak 30 responden di luar dari sampel penelitian.

Teknik pengumpulan data menggunakan angket atau kuesioner, yaitu memberikan seperangkat pertanyaan atau pernyataan tertulis oleh responden untuk dijawab (Sugiyono, 2018). Angket atau kuesioner yang diberikan kepada responden dengan menggunakan Google Form. Angket atau kuesioner diukur dengan skala Likert, sebagai berikut:

Tabel 1. Skala Likert

\begin{tabular}{clcc}
\hline No. & \multicolumn{1}{c}{ Alternatif Jawaban } & Skor Nilai Positif & Skor Nilai Negatif \\
\hline 1 & Sangat setuju & 5 & 1 \\
2 & Setuju & 4 & 2 \\
3 & Ragu-ragu & 3 & 3 \\
4 & Tidak setuju & 2 & 4 \\
5 & Sangat tidak setuju & 1 & 5 \\
\hline
\end{tabular}

Uji coba instrumen menggunakan uji validitas koefisien korelasi product moment, sedangkan perhitungan reliabilitas menggunakan alpha cronbach, dengan bantuan software SPSS versi 26.00

Uji validitas variabel motivasi wirausaha $(\mathrm{X})$ sebanyak 30 responden dan 18 butir pernyataan yang diujicobakan. Hasil uji coba menunjukkan bahwa, 17 butir valid dan 1 butir tidak valid atau drop. Koefisien reliabilitas adalah sebesar 0,899 . Butir pernyataan yang tidak valid atau drop tidak digunakan, koefisien reliabilitasnya menjadi 0,902. 


\section{Westri Andayanti, Subhan Harie \\ Universitas Indraprasta PGRI}

Uji validitas variabel minat berwirausaha mahasiswa (Y) sebanyak 30 responden dan 18 butir pernyataan yang diujicobakan. Hasil uji coba menunjukkan bahwa, 17 butir valid dan 1 butir tidak valid atau drop. Koefisien reliabilitas adalah sebesar 0,923 . Butir pernyataan yang tidak valid atau drop tidak digunakan, koefisien reliabilitasnya menjadi 0,925.

Perhitungan persyaratan analisis data pada penelitian ini menggunakan uji normalitas (Kolmogorov-smirnov) dan uji homogenitas (Levene). Analisis data penelitian menggunakan analisis regresi parsial dan simultan, uji korelasi dengan korelasi product moment dari Pearson, uji t, dan koefisien determinasi, semuanya menggunakan software SPSS versi 26.00.

\section{HASIL DAN PEMBAHASAN}

\section{Hasil}

Data mengenai hasil perhitungan statistik deskriptif motivasi wirausaha (X) dan minat berwirausaha mahasiswa (Y) menampilkan data mengenai mean, median, modus, standard deviantion, variance, range, minimum, maksimum, dan jumlah (sum) terdapat pada Tabel 2 sebagai berikut:

\section{Tabel 2. Hasil Perhitungan Statistik Deskriptif}

\begin{tabular}{|c|c|c|c|}
\hline & & Motivasi Wirausaha (X) & $\begin{array}{l}\text { Minat Berwirausaha } \\
\text { Mahasiswa (Y) }\end{array}$ \\
\hline \multirow[t]{2}{*}{$\overline{\mathrm{N}}$} & Valid & 94 & 94 \\
\hline & Missing & 0 & 0 \\
\hline \multicolumn{2}{|c|}{ Mean } & 62.81 & 67.82 \\
\hline \multicolumn{2}{|c|}{ Median } & 63.00 & 69.50 \\
\hline \multicolumn{2}{|c|}{ Mode } & 56 & 72 \\
\hline \multicolumn{2}{|c|}{ Std. Deviation } & 10.339 & 8.000 \\
\hline \multicolumn{2}{|c|}{ Variance } & 106.888 & 63.999 \\
\hline \multicolumn{2}{|c|}{ Range } & 42 & 37 \\
\hline \multicolumn{2}{|c|}{ Minimum } & 41 & 45 \\
\hline \multicolumn{2}{|c|}{ Maximum } & 83 & 82 \\
\hline \multicolumn{2}{|c|}{ Sum } & 6806 & 6375 \\
\hline
\end{tabular}

Hasil pengujian regresi parsial antara motivasi wirausaha terhadap minat berwirausaha mahasiswa terdapat pada Tabel 3 di bawah ini.

Tabel 3. Model Persamaan Regresi Linier Parsial $\hat{Y}=43,634+0,385 \mathrm{X}_{2}$

\begin{tabular}{llllll}
\hline \multirow{2}{*}{ Model } & \multicolumn{2}{l}{$\begin{array}{l}\text { Unstandardized Coefficients } \\
\text { STD. Error }\end{array}$} & $\begin{array}{l}\text { Standardized } \\
\text { Coefficients } \\
\text { Beta }\end{array}$ & T & Sig. \\
\hline $1 \quad$ B Constant $)$ & 43.634 & 4.454 & & 9.798 & .000 \\
Motivasi Wirausaha $\left(\mathrm{X}_{1}\right)$ & .385 & .070 & .498 & 5.503 & .000 \\
\hline
\end{tabular}

Sumber: Diolah (2020)

Hasil pengujian regresi parsial antara motivasi wirausaha terhadap minat berwirausaha mahasiswa membentuk model regresi yang signifikan dan linier, dirumuskan sebagai berikut: $\hat{Y}$ $=43,634+0,385 \mathrm{X}_{2}$. Persamaan tersebut menunjukkan bahwa, pengaruh motivasi wirausaha terhadap minat berwirausaha mahasiswa bernilai positif. Artinya apabila motivasi wirausaha bertambah satu skor, maka akan diikuti oleh kenaikan skor minat berwirausaha mahasiswa sebesar 0,385 dengan konstanta sebesar 43,634. 
Uji keberartian persamaan regresi antara motivasi wirausaha terhadap minat berwirausaha mahasiswa menggunakan uji ANOVA. Hasil uji regresi signifikansi disajikan pada Tabel 4 di bawah ini.

Tabel 4. ANOVA Uji Signifikansi Persamaan Regresi Linier Parsial

\begin{tabular}{lllllll}
\hline Model & & Sum of Squares & $\boldsymbol{d f}$ & Mean Square & F & Sig. \\
\hline 1 & Regression & 1473.925 & 1 & 1473.925 & 30.282 & .000 \\
& Residual & 4478.001 & 92 & 48.674 & & \\
& Total & 5951.926 & 93 & & & \\
\hline
\end{tabular}

Sumber: Diolah (2020)

Hasil pengujian keberartian model regresi pada $\alpha=0,05$ menunjukkan $F_{\text {hitung }}$ sebesar 30,282 lebih besar dari $\mathrm{F}_{\text {tabel (1:92) }}$ sebesar 3,94. Dengan demikian, $\mathrm{H}_{0}$ ditolak yang menunjukkan model regresi parsial $\hat{Y}=43,634+0,385 \mathrm{X}_{2}$ adalah signifikan.

Hasil pengujian linieritas pada model regresi $\hat{\mathrm{Y}}=43,634+0,385 \mathrm{X}_{2}$ pada $\alpha=0,05$ menunjukkan $\mathrm{F}_{\text {hitung }}$ sebesar 1,482 lebih kecil dari $\mathrm{F}_{\text {tabel (36:56) }}$ sebesar 1,59. Dengan demikian, $\mathrm{H}_{0}$ diterima sehingga bentuk pengaruh motivasi wirausaha terhadap minat berwirausaha mahasiswa adalah linier. Visualisasi pengaruh motivasi wirausaha terhadap minat berwirausaha mahasiswa dapat di lihat pada Gambar 1 di bawah ini:

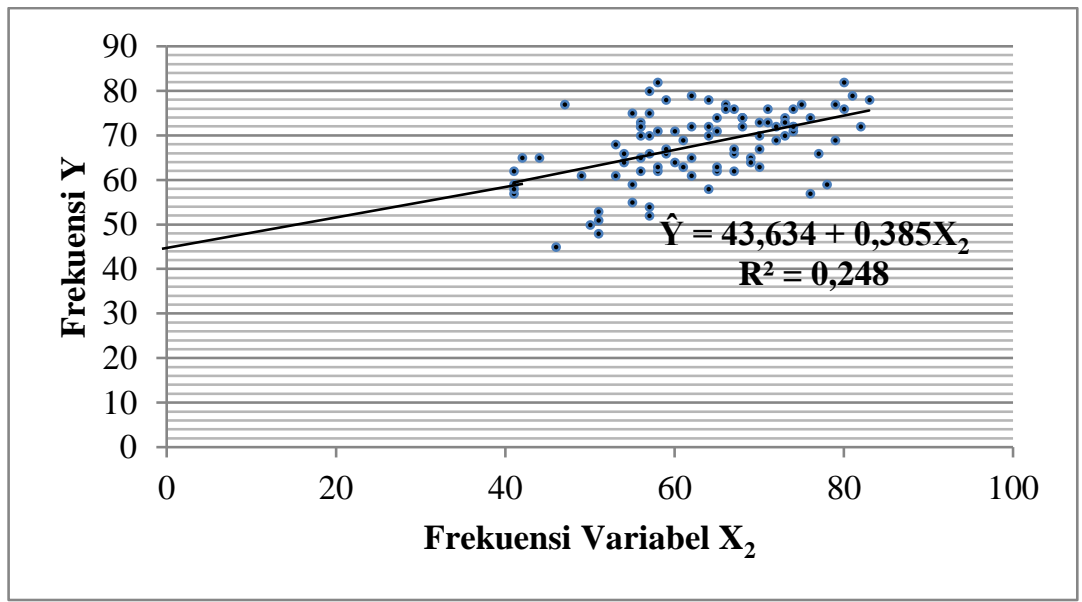

Sumber: Penulis (2020)

Gambar 1. Model Regresi Linier Motivasi Wirausaha (X) terhadap Minat Berwirausaha Mahasiswa (Y)

Perhitungan koefisien korelasi dengan menggunakan rumus Pearson product moment. Berdasarkan hasil perhitungan dan pengujian, diperoleh besarnya koefisien korelasi parsial yang terdapat pada tabel di bawah ini.

Tabel 5. Koefisien Korelasi Motivasi Wirausaha (X) terhadap Minat Berwirausaha Mahasiswa (Y)

\begin{tabular}{llll}
\hline & & $\begin{array}{l}\text { Motivasi } \\
\text { Wirausaha }\left(\mathbf{X}_{2}\right)\end{array}$ & $\begin{array}{l}\text { Minat Berwirausaha } \\
\text { Mahasiswa (Y) }\end{array}$ \\
\hline Motivasi Wirausaha $\left(\mathrm{X}_{2}\right)$ & Pearson Correlation & 1 & $.498^{* *}$ \\
& Sig. (2-tailed) & .000 \\
& N & 94 & 94 \\
& Pearson Correlation & $.498^{* *}$ & 1 \\
\hline
\end{tabular}

DOI PUBLIKASI https://doi.org/10.37010/int.v1i2 
Westri Andayanti, Subhan Harie

Universitas Indraprasta PGRI

\begin{tabular}{llll}
\hline Minat Berwirausaha & MahasiswaSig. (2-tailed) & .000 \\
$(\mathrm{Y})$ & $\mathrm{N}$ & 94 & 94 \\
\hline
\end{tabular}

Hasil perhitungan koefisien korelasi antara motivasi wirausaha terhadap minat berwirausaha mahasiswa menunjukkan sebesar 0,498 lebih besar dari $\alpha=0,05$. Dengan demikian, terdapat pengaruh atau hubungan positif dan sangat signifikan.

Uji signifikansi koefisien korelasi antara motivasi wirausaha terhadap minat berwirausaha mahasiswa yang terdapat pada Tabel 10, menunjukkan bahwa nilai $t_{\text {hitung }}$ sebesar 5,503 lebih besar dari $t_{\text {tabel }}(94$ pada $\alpha=0,05)$ sebesar 1,985. Berdasarkan hasil pengujian koefisien korelasi dan uji signifikansi koefisien korelasi, maka koefisien korelasi tersebut signifikan dan terdapat pengaruh antara motivasi wirausaha terhadap minat berwirausaha mahasiswa.

Uji koefisien determinasi dilakukan untuk mengetahui besarnya kontribusi motivasi wirausaha terhadap minat berwirausaha mahasiswa. Hasil uji koefisien determinasi terdapat pada Tabel 6 di bawah ini.

Tabel 6. Koefisien Determinasi Motivasi Wirausaha (X) terhadap Minat Berwirausaha Mahasiswa (Y)

\begin{tabular}{rllll}
\hline Model & R & R Square & $\begin{array}{l}\text { Adjusted } \\
\text { R Square }\end{array}$ & $\begin{array}{l}\text { STD.Error of The } \\
\text { Estimate }\end{array}$ \\
\hline 1 & .498 & .248 & .239 & 6.977 \\
\hline Sumber: Diolah $(2020)$ & & &
\end{tabular}

Berdasarkan hasil perhitungan diperoleh nilai koefisien determinasi pada $R$ Square sebesar $0,248 \times 100 \%=24,8 \%$. Hal ini dapat diinterpretasikan bahwa, motivasi wirausaha terhadap minat berwirausaha mahasiswa sebesar $24,8 \%$. Sedangkan sisanya sebesar $75,2 \%$ dipengaruh di luar variabel penelitian.

Berdasarkan hasil pengujian hipotesis kedua, diketahui bahwa secara parsial terdapat pengaruh motivasi wirausaha terhadap minat berwirausaha mahasiswa. Hal ini terbukti pada hasil persamaan regresi yang menunjukkan adanya hubungan atau pengaruh linier antara motivasi wirausaha terhadap minat berwirausaha mahasiswa. Artinya semakin meningkat motivasi wirausaha, maka semakin meningkat pula minat berwirausaha mahasiswa.

\section{Pembahasan}

Minat usaha secara parsial berpengaruh terhadap keberhasilan usaha para wirausaha muda. Motivasi usaha secara parsial berpengaruh terhadap keberhasilan usaha para wirausaha muda. Hal ini sesuai dengan hasil uji penelitian sebelumnya yang secara simultan menemukan hasil bahwa baik minat usaha maupun motivasi usaha secara bersama-sama berpengaruh secara signifikan terhadap keberhasilan usaha para wirausaha muda di Kota Langsa (Ardiyanti \& Mora, 2019).

Analisis regresi sederhana menunjukkan nilai konstan 31,438 dengan koefisien regresi variabel motivasi belajar sebesar 0,979. Hasil uji-t adalah 5,385 dengan nilai signifikansi $0,000(<0,05)$ yang berarti ada pengaruh yang signifikan antara motivasi belajar terhadap minat kewirausahaan (Widjaya, 2019).

Mahasiswa memiliki pemahaman materi mata kuliah kewirausahaan yang tinggi. Namun memiliki minat berwirausaha yang rendah. Hal ini juga terlihat pada penelitian sebelumnya yang menunjukkan pengaruh materi mata kuliah kewirausahaan terhadap minat berwirausaha mahasiswa Jurusan Manajemen Dakwah Fakultas Dakwah dan Ilmu Komunikasi IAIN Imam Bonjol Padang, dengan uji R square sebesar 0,150 atau sebesar 15\%, serta uji t 
dengan $t_{\text {hitung }}$ adalah 2,967 dan $t_{\text {tabel }}$ adalah 2,009, dengan signifikansi sebesar 0,005 $<0,05$. Karena $t_{\text {hitung }}$ lebih besar dari pada $t_{\text {tabel }}$ maka hipotesis diterima. Pembelajaran kewirausahaan berpengaruh signifikan terhadap minat berwirausaha mahasiswa (Fahmi \& Amanda, 2017).

Analisis data menggunakan uji $\mathrm{t}$ atau secara parsial yaitu antara pembelajaran kewirausahaan didapat nilai $t_{\text {hitung }}(2,482)>t_{\text {tabel }}(2,021)$ dengan signifikansi 0,018 sehingga ada pengaruh terhadap minat untuk berwirausaha mahasiswa. Analisis data uji t atau secara parsial yaitu antara Motivasi Berwirausaha didapat nilai $t_{\text {hitung }}(2,093)>t_{\text {tabel }}(2,021)$ dengan signifikansi 0,043 sehingga ada pengaruh terhadap minat untuk berwirausaha mahasiswa. Dari analisis data menggunakan uji $\mathrm{f}$ atau secara simultan yaitu antara pembelajaran kewirausahaan dan motivasi berwirausaha didapat nilai $F_{\text {hitung }}(8,073)>F_{\text {tabel }}(3,25)$ berpengaruh terhadap prestasi belajar siswa dengan signifikansi 0,001 sehingga ada pengaruh terhadap minat berwirausaha mahasiswa (Wardhani \& Rachmawati, 2019).

Minat Berwirausaha adalah seseorang yang memiliki kecenderungan, keyakinan, serta kesediaan dari dalam diri individu untuk siap menempuh segala resiko dengan perasaan senang dalam melakukan tindakan wirausaha. Hasil penelitian menunjukkan; ada pengaruh signifikan pengetahuan kewirausahaan terhadap minat berwirausaha dan ada pengaruh tidak langsung pengetahuan kewirausahaan terhadap minat berwirausaha melalui self efficacy sebesar $17,2 \%$; ada pengaruh signifikan Motivasi belajar terhadap minat berwirausaha dan ada pengaruh tidak langsung motivasi belajar terhadap minat berwirausaha melalui self efficacy sebesar 15,3\%; ada pengaruh signifikan status sosial ekonomi orang tua terhadap minat berwirausaha dan ada pengaruh tidak langsung status sosial ekonomi orang tua terhadap minat berwirausaha melalui self efficay sebesar 16,8\% (4) Ada pengaruh signifikan self efficacy terhadap minat berwirausaha (Jailani, Rusdarti, \& Sudarma, 2017).

\section{PENUTUP}

Temuan penelitian menunjukkan bahwa, terdapat pengaruh parsial yang positif dan signifikan motivasi wirausaha terhadap minat berwirausaha mahasiswa. Artinya semakin meningkat motivasi wirausaha, maka semakin meningkat pula minat berwirausaha mahasiswa. motivasi wirausaha, maka semakin meningkat pula minat berwirausaha mahasiswa. Kesimpulan dari hasil penelitian ini adalah variabel motivasi wirausaha bukan satu satunya variabel yang mempengaruhi minat berwirausaha, namun perlu juga dikembangkan penelitian pada variabel lain untuk mendapatkan pembaruan.

\section{DAFTAR PUSTAKA}

Ardiyanti, D. A \& Mora, Z. (2019). Pengaruh Minat Usaha dan Motivasi Usaha terhadap

Keberhasilan Usaha Wirausaha Muda di Kota Langsa. Jurnal Samudra Ekonomi dan Bisnis Volume 10 Nomor 2 Juli, 168-178.

Atmaja, A. T. M. (2016). Pengaruh Pendidikan Kewirausahaan dan Aktivitas Wirausaha Terhadap Minat Berwirausaha Mahasiswa Universitas Negeri Semarang. Economic Education Analysis Journal Volume 5 Nomor 3 Oktober, 774-787.

Basrowi. (2016). Kewirausahaan: Untuk Perguruan Tinggi. Bogor: Ghalia Indonesia.

Bungin, B. (2017). Metodologi Penelitian Kuantitatif, Komunikasi, Ekonomi, dan Kebijakan Publik Serta Ilmu-Ilmu Sosial Lainnya. Jakarta: Kencana.

Crow, D. Leater \& Crow, Alice. (1989). Psikologi Pendidikan. Yogyakarta: Nur Cahaya.

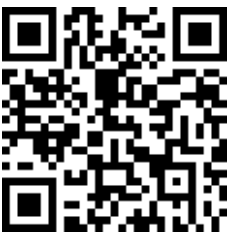

DOI PUBLIKASI https://doi.org/10.37010/int.v1i2 


\section{Westri Andayanti, Subhan Harie Universitas Indraprasta PGRI}

Direktorat Jenderal Pembelajaran dan Kemahasiswaan Kementerian Riset, Teknologi, dan Pendidikan Tinggi. (2015). Pedoman Program Mahasiswa Wirausaha (PMW). Jakarta: Kementerian Riset, Teknologi, Dan Pendidikan Tinggi.

Fahmi, R \& Amanda, T. (2017). Pengaruh Pembelajaran Kewirausahaan terhadap Minat Berwirausaha Mahasiswa. JEBI (Jurnal Ekonomi dan Bisnis Islam) Volume 2 Nomor 1, Januari-Juni, 1-10.

Fahmi, I. (2014). Kewirausahaan Teori, Kasus, dan Solusi. Bandung: Alfabeta.

Gemina, D., Silaningsih, E. dan Yuningsih, E. (2016). Pengaruh Motivasi Usaha terhadap Keberhasilan Usaha dan Kemampuan Usaha sebagai Variabel Mediasi pada Industri Kecil Menengah Makanan Ringan Priangan Timur - Indonesia. Jurnal Manajemen Tekno logi Volume 15 Nomor 3 Oktober, 297-323.

Jailani, M., Rusdarti, \& Sudarma, K. (2017). Pengaruh Kewirausahaan, Motivasi Belajar, Sosial Ekonomi Orang Tua dan Self Efficacy Terhadap Minat Berwirausaha Siswa. Journal of Economic Education Volume 6 Nomor 1, 52-59.

Minola, T., Criaco, G. dan Obschonka, M. (2016). Age, Culture, and Self-Employment Motivation. Springer Link, Small Business Economics Volume 46 Nomor 2 October, 187-213.

Moore, J. L., Dickson-Deane, C., \& Galyen, K. (2011). E-Learning, online learning, and distance learning environments: Are they the same?. The Internet and Higher Education Volume 14 Nomor 2 March, 129-135.

Mulyadi. (2015). Manajemen Sumber Daya Manusia. Jakarta: Penerbit In Media. Prawiradilaga, D. S. (2015). Prinsip Desain Pembelajaran. Jakarta: Kencana.

Ramadhani, N. T., \& Nurnida, I. (2017). Pengaruh Mata Kuliah Kewirausahaan Terhadap Minat Berwirausaha Mahasiswa. Journal Ecodemica Volume 1 Nomor 1 April, 89-97.

Sugiyono. (2018). Metode Penelitian Evaluasi (Pendekatan Kuantitatif, Kualitatif, dan Kombinasi). Bandung: CV Alfabeta.

Sunyoto, D. (2012). Manajemen Sumber Daya Manusia. Jakarta: PT Buku Seru.

Suryani \& Hendryadi. (2016). Metode Riset Kuantitatif, Teori dan Aplikasi Pada Penelitian Bidang Manajemen dan Ekonomi Islam. Jakarta: Kencana.

Wardhani, R. A. N., \& Rachmawati, S. (2019). Pengaruh Pembelajaran Kewirausahaan dan Motivasi terhadap Minat untuk Berwirausaha Mahasiswa IKIP PGRI Jember. Jurnal Equilibrium Volume 7 Nomor 1 Januari, 52-57.

Wikanso. (2013). Pengaruh Pendidikan Kewirausahaan terhadap Motivasi Berwirausaha Mahasiswa STKIP PGRI Ngawi. Media Prestasi: Jurnal Ilmiah STKIP Ngawi Volume 11 Nomor 1 Juni, 1-15.

Wiyadi, H. dan Rochmania, D. D. (2016). Pengaruh Mata Kuliah Kewirausahaan dan Motivasi Diri Terhadap Minat Berwirausaha Mahasiswa Unhasy Jombang. Discovery: Jurnal Ilmu Pengetahuan Volume 1 Nomor 2 Februari, 1-35.

Yusuf, M. (2016). Metode Penelitian Kuantitatif, Kualitatif, dan Penelitian Gabungan. Jakarta: Kencana. 